Journal of Teacher Education for Sustainability, vol. 18, no. 2, pp. 53-65, 2016

\title{
Teachers' Perceptions of the Relationship between Inclusive Education and Distributed Leadership in two Primary Schools in Slovakia and New South Wales (Australia)
}

\author{
Jozef Miškolci \\ Comenius University in Bratislava, Slovakia \\ Derrick Armstrong \\ University of the South Pacific, Suva, Fiji \\ Ilektra Spandagou \\ The University of Sydney, Australia
}

\begin{abstract}
The academic literature on the practice of inclusive education presents diverse and at times contradictory perspectives in how it is connected to practices of distributed leadership. Depending on the approach, on the one hand, inclusive educational practice may enable distributed school leadership, while on the other hand, it may allow for hierarchical management styles if staff members do not implement inclusive practices. This paper explores how school staff members perceive and understand the relationship between practices of inclusive education and distributed leadership in two public primary schools: one in New South Wales (Australia) and one in Slovakia. These two schools were identified by external informants as good practice examples of inclusive education. Using qualitative research methods based on interviews, this paper identifies two main understandings of this relationship. First, although distributed leadership may encourage the goals of inclusive education, it may in some circumstances also hinder their achievement. Second, distributed leadership can be constructed as an indispensable component of inclusive education, and this has implications for how the target groups of inclusive education are conceptualised. This paper also discusses the wider social and political contexts of the two primary schools and how in each case context significantly constrained and shaped understandings and practices of inclusion and distributed leadership in the practice of teachers and principals.
\end{abstract}

Keywords: inclusive education, distributed leadership, policy, practice 


\section{Introduction}

In many countries there continues to be an increase in the number of students assessed as having special educational needs (SEN), including Australia (Graham \& Jahnukainen, 2011) and Slovakia (Žovinec \& Seidler, 2010). Despite, the global rhetoric of inclusive education, fuelled primarily by the Organisation of United Nations and its international policy initiatives, such as UNESCO's Salamanca Statement on Principles, Policy and Practice in Special Needs Education (Armstrong, Armstrong, \& Spandagou, 2010), many practitioners and academics have questioned the extent to which inclusive education practices occur in schools. It is important to clarify inclusive education as discussed in this paper. Many authors have made the point that there isn't a commonly accepted definition of inclusion (Armstrong et al., 2010). While the authors of the paper support a broad understanding of inclusion relevant to the reform of educational systems and schools, it needs to be acknowledged that in the two educational systems examined in this study, inclusive education tends to be focused on students with special educational needs and/or disabilities. This is also the case of the literature on inclusive education discussed in the paper.

Regardless of what is seen as the focus of inclusion, there is consensus that practising inclusion is not only about teaching and adjusting the curriculum, but that it is also a whole-school matter very closely related to how leadership is organised and practised in the school (e.g., Booth \& Ainscow, 2011; Ward et al., 2015). That is also to say that inclusive education calls for the redirection of the whole school culture, especially for the change to be sustainable (Bērziña, 2010). In this sense, 'sustainable' in the context of 'inclusive education' does not only mean to make a change in school climate, policies and practices or the whole state school system towards inclusion, which remains to be in place in a long run (Ballard, 2013; Gill, Sherman \& Sherman, 2009; McMaster, 2015; Sindelar, Shearer, Yendol-Hoppey \& Liebert, 2006), but also to provide basis for responsibility, activism, critical inquiry and social equality as such (Kairiene \& Sprindziunas, 2016; Nelson, Cassell \& Arnold, 2013; Starks, 2013; Zaķe, 2010).

If considering the literature, which focuses on inclusive education at a school level, the form of school leadership is often scrutinised. Besides investigating the role of principals in bringing about inclusion in their schools (e.g., Cobb, 2015; Riehl, 2000; Wood, Spandagou \& Evans, 2012) and their attitudes towards inclusive education (e.g., Graham \& Spandagou, 2011), several authors have insisted that in looking at school inclusion the meaning of school leadership must be extended beyond the role and influence of the principal. For instance, the Index for Inclusion (Booth \& Ainscow, 2011, p. 99) presents an 'inclusive approach to leadership' as one of the indicators that should be adopted when considering the development of inclusive policies and practices. In the context of the 'Index' this indicator involves a form of collaborative leadership amongst the school community, in contrast to what can be called an autocratic approach to leadership. In the former case, knowledge-sharing takes place amongst staff, and staff members are able to contribute to decision-making processes and their input is respected.

Developing a similar line of argument, Angelides, Antoniou, and Charalambous (2010) portray principals as the ones who should empower others. Kugelmass and Ainscow (2004) go even further in this respect. While calling for the 'positional' leaders (the principals) to support 'distributed leadership and participative decision-making', they argue that principals should be 'autocratic' when introducing the values and beliefs central to inclusive education (pp. 139-140). In a more recent study, Ainscow and 
Sandill (2010) advocate for 'distributed leadership' (p. 405) but they still portray principals as the only ones responsible for challenging the hierarchical structures in schools whilst promoting inclusive values and encouraging other school stakeholders to participate in leadership functions. These studies gloss over the relationship between distributed leadership and inclusive education and particularly the question of whether or not the former is a condition of the latter being genuinely achieved in a school setting.

However, the extensive research on teachers' attitudes towards inclusive education shows that teachers often feel that they do not have sufficient time, skills and training to support their attempts to introduce inclusive educational practices in their classrooms and schools (Rajovic \& Jovanovic, 2013). In principle teachers may be supportive of inclusion, in these studies understood as the education of students with SEN or disabilities together with other students in regular classrooms of regular schools. However they also frequently express rather negative attitudes toward the inclusion of students with more severe disabilities or students with behaviour difficulties because of concerns about the impact upon the education of other children in the class (Avramidis \& Norwich, 2002; de Boer, Pijl \& Minnaert, 2011). Therefore, in some circumstances, distributing school leadership may work against the broader interests of school inclusion because it places too much responsibility in the hands of those who lack the skills and experience to lead whole school change. In this case, consensus between the school community, and especially staff, may support a status quo that is derived from a fear of the consequences of change and an inability to see beyond the present situation. It may simply reflect the absence of transformational leadership and the latter it might be argued is more significant to bringing about inclusive practices in schools than a vaguely democratic notion of distributive leadership. In other words, in the situation where school stakeholders have reserved attitudes towards inclusion, distributed leadership may result in obstacles against inclusion.

In response to these concerns, it might be argued that they rest upon a very limited view of the concept and dynamics of distributed leadership. In the academic field of school leadership and administration, the concept of distributed leadership has been defined in very different ways (Bolden, 2011). It can be understood as a purely descriptive term (Spillane, 2010) or normative as a potential strategy for school improvement (Harris, 2013; Woods \& Gronn, 2009). As in the case of inclusive education, several theorists of distributed leadership also critically scrutinise the socio-political context and point out the impact of power relations on the application of the concept in the everyday practices of schools (Hall, Gunter, \& Bragg, 2013; Hartley, 2010; Lumby, 2013). Neoliberal discourses of managerialism, efficiency, and individualism in the educational policies of countries like Australia (Welch, 2010) and Slovakia (Kaščák \& Pupala, 2012) may create an insurmountable barrier to the practice of distributed leadership (Hall et al., 2013; Hatcher, 2005; Leo \& Barton, 2006; Ward et al., 2015) and inclusive education (Armstrong, Armstrong \& Spandagou, 2011; Ballard, 2013; Hardy \& Woodcock, 2015; Slee, 2013). These wider socio-political factors are often not spoken of in discussions of sustainability of collaboration, distribution of responsibilities, involvement in decisionmaking processes and inclusion of all students in schools.

In this article we explore the relationship between teacher understanding of inclusive education practices and distributed leadership as presented by staff members from two public primary schools - one in New South Wales (NSW), Australia and one in Slovakia. The schools were chosen on the recommendation of senior education administrators in 
each location as exemplifying good practice examples of inclusive education. The article considers the proposition that inclusive education requires distributed leadership in school management if inclusion is to be enhanced and properly supported (e.g., Ainscow \& Sandill, 2010; Booth \& Ainscow, 2011; Kugelmass \& Ainscow, 2004). Our study aims to provide an insight into how these two concepts relate to each other, and to contribute to the theorisation of this relationship.

\section{Methods}

The two public primary schools were selected for this study through 'purposeful sampling' (Schensul, 2012, p. 84). A number of academics, non-governmental organisations and public administration institutions dealing with issues of inclusive education were contacted to identify 'good practice' examples of inclusive public primary schools in Slovakia and NSW. The research itself makes no judgment about whether or not these schools did exemplify good practice. The intention was rather to examine the practice of distributed leadership and inclusive education and the features we wished to observe were judged more likely to be evident in schools that were generally considered by knowledgeable insiders to be exemplars of 'good practice'.

The NSW school had approximately 100 students, four regular classrooms (Kindergarten, Year 1-2, Year 3-4, Year 5-6), five full-time teachers and one teaching principal and it was located in urban area. The Slovak school had approximately 250 students, nine regular classrooms (one classroom per year from Year 1 to Year 9) and sixteen special classrooms only for students diagnosed with SEN or disability. The school had approximately 30 full-time teachers, one teaching principal and one teaching deputy principal and it was also located in the urban area. Neither of these schools is 'typical' of their setting and there were, of course, significant differences between these schools in terms of size, structure, and the policy contexts of operation. These factors were not unimportant in respect of the comparison of practices between them. However, the intention was not to examine differences and similarities in these respects or to generalise from one school to all schools in each context. Rather, we were concerned with the inter-relationship between distributed leadership and inclusive education in the practice of teachers and principals.

After staff members of both schools expressed their consent to participate in the study, the first author spent four months in each school (from mid-July till mid-November 2011 in the NSW school and from mid-November 2011 until end of March 2012 in the Slovak school) as a volunteer teacher's aide (two days per week). This article focuses on the data from interviews with staff members of the two schools. In the NSW school all staff members (the principal, four classroom teachers, an English as a Second Language (ESL) teacher and a non-teaching staff member) were interviewed, while in the Slovak school a selection of staff members (the principal, deputy principal, special education teacher and five classroom teachers) participated in the semi-structured individual interviews. The interviewees were asked three main questions and prompted to elaborate on them in detail: 1) how they understand the term 'inclusive education' and how it is practised in their school; 2) how they understand the term 'distributed leadership'; and 3 ) the relationship between these two terms. 


\section{Results}

\section{Understanding the Concepts of Inclusive Education and Distributed Leadership}

When being asked about their understanding of the concept of 'inclusive education', staff members in both schools consistently constructed it as a set of goals or aims to be fulfilled. These goals included (listed from the most frequent answers to the least): 1) enhancing educational results and skills of all students; 2) developing all students' unique potential; 3) developing good and ethical behaviour in all students; 4) enabling all students to experience happiness, belonging, and self-worth; 5) enabling them to actively participate.

By contrast, staff members in both schools understood 'distributed leadership' as a set of processes. These processes involved primarily (listed from the most frequent answers to the least): 1) collaboration among all staff members; 2) staff equal involvement in decisionmaking processes; 3 ) taking on responsibilities and projects by all individual staff members. Thus, while inclusive education was constructed as a set of goals targeting exclusively students, distributed leadership related exclusively to processes involving staff members.

\section{Understanding Distributed Leadership as a Means to Inclusive Education}

After being asked about their understanding of the concepts of 'inclusive education' and 'distributed leadership', the interviewees were also questioned about how they understood the relationship between the two concepts. The majority of staff members in both schools (five out of seven in the NSW school; six out of eight in the Slovak school) perceived distributed leadership as a means to practise inclusive education. They considered the main processes of distributed leadership as conducive and beneficial to the practice of inclusive education.

For instance, teachers in the NSW school particularly strongly associated distributed leadership with the process of performing leadership responsibilities and leading various school projects and subsequently connected this manifestation of distributed leadership with what they saw as the practice of inclusive education.

The more people [staff members], I think, that you've got involved in projects and programs for our kids, it stands to reason that the more you are going to be able to diversify the opportunities. So I think it works for the kids, because you are getting increased expertise and access for the children. (Principal, NSW school)

I think from a purely pragmatic point of view it is too much for one person to handle. I also think that it's important as, if we believe in inclusive practice, then we believe in providing students with opportunities that extend beyond the classroom. And in order for those opportunities to be realised and to be realised across the school, it involves us working together as teachers to provide those opportunities. (Staff member, NSW school)

Besides associating the concept of distributed leadership with performing various leadership responsibilities, staff members in both schools understood it as 'sharing' various responsibilities and 'collaborating'. The deputy principal of the Slovak school expressed a view that collaboration among teachers and between staff members and 
parents plays a crucial part in attempting to achieve the inclusive goal of enabling students to 'thrive' or 'prosper'. In this way, the interviewee alluded to the goal of enhancing students' educational outcomes and skills.

It is also about when they [teachers] see, for instance, that a child is thriving when working in this particular way, they share it amongst each other. And in our school the work would not be possible without mutual collaboration, because what we do here is really teamwork. That special education teacher, parent, teacher, there really must be collaboration. We see that with children, where there is no collaboration, they do not prosper. (Deputy principal, Slovak school)

A NSW teacher described how collaboration between staff supported the achievement of inclusive education goals.

I am convinced that we discuss issues of inclusive education to a great extent here. We usually do so at professional development meetings, but also during informal break times. At staff meetings we discuss individual cases of students so all teachers are informed about various students, even if we are not part of their classrooms. In this sense all teachers act as a resource for each other. They give particular advice to each other by saying, for instance, 'You can try this or that'. (Staff member, NSW school)

Last but not least, staff members, who associated the concept of distributed leadership primarily with the process of involvement in decision-making, also saw it as connected to inclusive education. For example the school principal argued that

You [as a principal] simply cannot direct and encompass everything, you have no chance to encompass what happens in the classroom. ... Because when you sit in the principal's office, you cannot decide about, for instance, what the teacher should reduce or expand the lesson content for a particular student or if she/he should be sent for [assessment]. I just can't imagine that. Or how to adjust her/his plans. It must be in the jurisdiction of that teacher and dependent on her/his decisions whether the child should be sent for an assessment or whether that child should be transferred to [a special classroom]. (Principal, Slovak school)

This principal aptly pointed out that decisions, which extended beyond everyday teaching situations, such as placing or transferring a child in a special or regular classroom, have to be made by a range of school stakeholders acting in collaboration with one another.

Constructing distributed leadership in terms of it being a means for attaining the goals of inclusive education implies that the processes of distributed leadership are distinct and external to practices and goals of inclusive education. This understanding may also imply the existence of other means for the attainment of these goals, such as professional learning or support services. Hence, in these terms the processes of distributed leadership might be considered as merely conducive to the goals of inclusive education, hence, not necessary or unavoidable. For instance, a scenario might emerge in which teachers holding disapproving attitudes towards inclusive education would put their position into practice through distributed decision-making processes. Hence, through 
distributed decision-making regular classroom teachers might instigate and bring about the transfer of student 'diagnosed' with SEN or disability to a segregated special classroom when this is an option. Thus, although inclusive practices may be enhanced through the operation of distributed leadership, the former is by no means ensured by the practice of the latter.

\section{Understanding Distributed Leadership as a Component of Inclusive Education}

Apart from those participants in the research who constructed distributed leadership as a means to achieving the goals of inclusive education, two research participants in each school, including the principals, also constructed it as an indispensable component of inclusive education itself.

I think if you value that, people are going to be respected, they are going to be treated fairly, they are going to at least be included - that to me is part of what we are defining as an inclusive school, that people have to feel that they are involved in the process of evaluation and of comment and of providing ideas. (Principal, NSW school)

I think they are very intertwined that without [distributed leadership], inclusion would not work as it should. I think it is very intertwined and without everybody being involved it would not work. (Principal, Slovak school)

In the first quote, the principal of the NSW school constructed the meaning of inclusive education, or an 'inclusive school', as comprising the involvement of all school stakeholders, (teachers, parents and students) in decision-making processes as one of the essential features of distributed leadership. In the second quote, the principal of the Slovak school did not specify a particular characteristic of distributed leadership, but constructed it as an indispensable component of inclusive education.

In addition to the decision-making processes, the principal of the NSW school and one staff member in the Slovak school also referred to teamwork and collaboration as important components of inclusion.

I would have to identify teamwork as a crucial component of successful inclusive schools. I truly believe that, but I would also have some evidence to also show that's the case. (Principal, NSW school)

The inclusion should be like that where we live as in one family, that people have those mutual relationships. At least I imagine it this way... that the leadership would closely collaborate with teachers and the teacher with leadership. (Staff member, Slovak school)

These two research participants understood 'collaboration' or 'teamwork' to be a form of distributed leadership. Yet, they also constructed this particular form of distributed leadership as overlapping with the meaning of inclusive education; not as an unrelated or secondary benefit, but as an indispensable component of a truly inclusive educational environment.

Without referring to particular processes of distributed leadership or goals of inclusive education, another staff member in the NSW school conveyed the meanings of distributed leadership and inclusive education as overlapping in their 'value' basis. 
If we didn't have the sort of approach to leadership that we do have, we wouldn't be reflecting what our values are. And if we are not reflecting what our values are, then our practice changes. And our practice starts to become less inclusive and it starts to become more autocratic... and if it's becoming autocratic then that's got to be sort of an opposing dialectic to inclusivity. (Staff member, NSW school)

This participant conveyed her/his view that there are different 'approaches' to leadership; her/his own was fundamentally grounded on inclusive 'values' in contrast to more 'autocratic' models of leadership that were perceived as being directed towards a value system seen as being opposed to the principles and practices of inclusivity. In other words, in her/his understanding of distributed leadership it is by definition inclusive - at least inclusive towards the adults or teachers. However, the possibility remains that while distributed leadership may be based on inclusive values in relation to interactions between teachers or between adults more generally, at the same time it may also be directed towards non-inclusive goals or outcomes when approaching students.

Therefore, we would argue that one can distinguish two forms of processes in the practice of distributed leadership: 1) those that incorporate inclusive goals and which are directed towards inclusive goals and outcomes; and 2) those that are not directed towards any particular goals and can equally lead to instances of exclusion of particular students. In other words, the first form of distributed leadership is understood not only in terms of processes, but also as a set of values and goals. The second form of distributed leadership is constructed as a mere set of processes without any directedness towards agreed values of inclusivity. In this respect, only the first form of distributed leadership should be considered as a component of inclusive education and overlapping with it.

In this broad understanding of inclusive education and distributed leadership the process becomes as important as the goal. In this sense, the process itself becomes one of the goals, which makes the boundaries between the concepts of a goal and process blurry and malleable. This understanding not only challenges the dominant construction of inclusive education (among the research participants) as a set of goals, it also challenges the exclusive target group of these goals to be the students and brings adults both in and outside the classroom into the picture. If distributed leadership represents an indispensable component of inclusive education, the latter must target not only students but also adult school stakeholders. Thus, the broad understanding of inclusive education must be conceptualised as representing both processes and goals and be concerned with the experiences and outcomes for both students and adults. While distributed leadership, understood as a mere process, can be perceived as inclusive in the limited sense we have described in the absence of inclusive value directedness and 'goal' orientation, it falls well short in supporting and enhancing a genuinely inclusive classroom and school. In other words, in this broad understanding of inclusive education the use of any practices of autocratic leadership have to be deemed to be non-inclusive; no matter what the intended goal of these autocratic processes. This remains the case even if the goal is that of the inclusion of students. 


\section{Discussion}

The narrow understanding of distributed leadership as a means for attaining inclusive goals is also dominant in academic literature, which focuses on inclusive education practised at a school level (e.g., Ainscow \& Sandill, 2010; Booth \& Ainscow, 2011; Kugelmass \& Ainscow, 2004). Some respondents, however, went beyond this narrow understanding of distributed leadership and inclusive education and constructed the former as an indispensable component of the former. This broad understanding of inclusive education and distributed leadership problematises the invitation to practise autocratic leadership as justifiable for the inclusive ends (Kugelmass \& Ainscow 2004, pp.139-140). This advice leaves an impression that without the principal's support for inclusion, there is no opportunity for teachers to pursue the goal. Inevitably this perspective undermines other school community members in their attempts to pursue inclusive goals. In particular, it disregards the extent to which both leadership and school practices and outcomes may be realised through disputed positions and interactions. These may themselves contribute to alternative constructions of 'school leadership' which challenge the dominant position of the principal.

Endeavouring to practise inclusive education or distributed leadership cannot be considered as something isolated from the social and political context. This claim was confirmed by some participants of this research study, as well.

The other thing you might need to know too is in terms of our NAPLAN results, we are expected also to monitor some individual programs - individual targets for individual kids who may not be at a minimum national standard. That's a requirement also of our system in terms of monitoring things like that.... We would be required for accountability purposes to show ways that we are setting targets for kids on minimal levels of achievement and we need to show how we've progressed their development. (Principal, NSW school)

In this statement the principal referred to NAPLAN (National Assessment Program Literacy and Numeracy) which is an annual assessment for all students in Year 3, 5, 7 and 9 in Australia. It was launched in 2008 (http://www.nap.edu.au/). In a staff meeting exclusively devoted to discussing the NAPLAN results, a number of staff members in the NSW school implied a dilemma. While on the one hand they expressed inclusive intentions to accept every single student who applied to their school, on the other hand they worried that accepting too many 'low achievers' in NAPLAN might create a negative reputation for the school as being underperforming or failing, discouraging more affluent or 'aspirational' parents from enrolling their children in the school. Although none of the research participants directly articulated this perspective in their interviews there was consistency in the interviews in teachers' conceptualisation of inclusion as in some way an endeavour to continually improve and change the school, including improving its appeal to a wider group of parents. In fact, in neither of the researched schools did the participants express deeper critical reflection of their practices and perceptions of inclusive education from a wider social, political or philosophical perspective (Ryan, 2006). This suggests some level of disconnect between the principles that teachers hold in relation to inclusivity in their classrooms and schools and the reality they experience in the face of external pressures over which they perceive themselves to have little or no control. These contextual variables are likely to be significant factors impacting upon practices within schools in relation to inclusivity. 
A number of academics in the field of inclusive education do not consider inclusion to be adequately analysed when considered only as a matter of organisational adjustments at a school level. From this socio-critical perspective, inclusion is also 'a theory and tactic for education and social reform' (Armstrong et al., 2010; Ballard, 2013; Fulcher, 1989; Hardy \& Woodcock, 2015), a 'political struggle' (Slee, 2011, p. 110), and a continuous struggle without any fixed outcome (Armstrong et al., 2010, p. 33). They critique the neoliberal discourses of 'school improvement, performativity, and standardisation' as impeding inclusion and social justice (Allan, 2008) and hindering the acceptance of difference and diversity (Grimaldi, 2012, p. 1131). The research participants in our study placed emphasis on enhancing students' educational outcomes as the primary goal of inclusive education and only occasionally referred to other goals (e.g., developing ethical behaviour in all students, enabling them to actively participate and experience happiness, belonging, and self-worth). This could be interpreted as reflecting the dominance of the 'educational excellence' discourse.

The wider social and political context, dominated by the neoliberal value system and deficit discourses of disability and special educational needs, both in NSW (Graham \& Jahnukainen, 2011; Slee, 2011) and Slovakia (Kaščák \& Pupala, 2011; Žovinec \& Seidler, 2010), may be inconsistent with an inclusive value system and may pose significant challenges to the sustainability of inclusion in schools (Armstrong, Armstrong \& Spandagou, 2010, p. 110). Thus, one needs to be careful not to put all the responsibility on teachers and schools for failing to practise inclusive education. Nonetheless, despite the potency of exclusionary ideologies and discourses in our societies, even those school principals and teachers who are conscious of these still have to face the reality of 'what to do on Monday morning' (Allan, 2008). The debate over what it means to practise inclusive education in classrooms and schools remains significant. While the concept of inclusive education might refer to a much larger socio-political reform project, to which each of us may contribute in her/his own way, teachers and other school stakeholders have a critical voice and role to play in conceptualising inclusive education and developing ways that can best support their schools in practising inclusive education.

\section{Conclusion}

This article has provided some insights on the linkages between inclusive education and distributed leadership. It has been argued that inclusive education can be understood, broadly, both as a set of goals and processes and as targeting student and adult stakeholders. However, it was also argued that practising inclusive education at school and classroom level cannot take place in isolation from the wider socio-political context, which promotes very powerful ideas and discourses that may be inconsistent with the inclusive ideals of teachers. That is why, practising an endless 'critical reflection', understood as 'the examination of personal and professional belief systems, as well as the deliberate consideration of the ethical implications and effect of practices' (Ward et al., 2015 , p. 342) is necessary if one wishes to minimise the impact of wider socio-political exclusionary discourses and pursue the inclusive values, goals and processes in everyday lives of schools. Seeing this as not simply an individual exercise but rather as a collaborative project is essential in problematising in practice the linkages between inclusive education and distributed leadership. 


\section{Funding}

This work was supported by the Australian Government, Department of Innovation, Industry, Science and Research [2010 International Postgraduate Research Scholarship]; the University of Sydney [2010 International Postgraduate Award] and the Faculty of Education and Social Work, University of Sydney [Thomas T. Roberts Education Fellowship 2011].

\section{References}

Ainscow, M., \& Sandill, A. (2010). Developing inclusive education systems: The role of organisational cultures and leadership. International Journal of Inclusive Education, 14(4), 401-416.

Ainscow, M., \& West, M. (Eds.). (2006). Improving urban schools: Leadership and collaboration. Buckingham: Open University Press.

Allan, J. (2008). Rethinking inclusive education: The philosophers of difference in practice. Dordrecht: Springer.

Angelides, P., Antoniou, E., \& Charalambous, C. (2010). Making sense of inclusion for leadership and schooling: A case study from Cyprus. International Journal of Leadership in Education, 13(3), 319-334.

Armstrong, A. C., Armstrong, D., \& Spandagou, I. (2010). Inclusive education: International policy \& practice. Thousand Oaks, California: Sage.

Armstrong, D., Armstrong, A. C., \& Spandagou, I. (2011). Inclusion: By choice or by chance? International Journal of Inclusive Education, 15(1), 29-39.

Avramidis, E., \& Norwich, B. (2002). Teachers' attitudes towards integration/inclusion: A review of the literature. European Journal of Special Needs Education, 17(2), 129-147.

Ballard, K. (2013). Thinking in another way: Ideas for sustainable inclusion. International Journal of Inclusive Education, 17(8), 762-775.

Bērziņa, Ž. (2010). Teachers' perceptions on what inclusion needs. Journal of Teacher Education for Sustainability, 12(1), 75-84.

Booth, T., \& Ainscow, M. (2011). Index for inclusion: Developing learning and participation in schools. Bristol: Center for Studies on Inclusive Education.

Cobb, C. (2015). Principals play many parts: A review of the research on school principals as special education leaders 2001-2011. International Journal of Inclusive Education, 19(3), 213-234.

Crawford, M. (2012). Solo and distributed leadership: Definitions and dilemmas. Educational Management Administration \& Leadership, 40(5), 610-620.

de Boer, A., Pijl, S. J., \& Minnaert, A. (2011). Regular primary schoolteachers' attitudes towards inclusive education: A review of the literature. International Journal of Inclusive Education, 15(3), 331-353.

Fulcher, G. (1989). Disabling policies? A comparative approach to educational policy and disability. London: The Falmer Press.

Gill, P., Sherman, R., \& Sherman, C. (2009). The impact of initial field experience on pre-service teachers' attitudes toward inclusion. Journal of Teacher Education for Sustainability, 11(2), 3-13. 
Graham, L. J., \& Jahnukainen, M. (2011). Wherefore art thou, inclusion? Analysing the development of inclusive education in New South Wales, Alberta and Finland. Journal of Education Policy, 26(2), 263-288.

Graham, L. J., \& Spandagou, I. (2011). From vision to reality: Views of primary school principals on inclusive education in New South Wales, Australia. Disability \& Society, 26(2), 223-237.

Grimaldi, E. (2012). Neoliberalism and the marginalisation of social justice: The making of an education policy to combat social exclusion. International Journal of Inclusive Education, 16(11), 1131-1154.

Hall, D. J., Gunter, H., \& Bragg, J. (2013). The strange case of the emergence of distributed leadership in schools in England. Educational Review, 65(4), 467-487.

Hardy, I., \& Woodcock, S. (2015). Inclusive education policies: Discourses of difference, diversity and deficit. International Journal of Inclusive Education, 19(2), 141-164.

Hatcher, R. (2005). The distribution of leadership and power in schools. British Journal of Sociology of Education, 26(2), 253-267.

Kairiene, B., \& Sprindziunas, A. (2016). Social equality as groundwork for sustainable schooling: The free lunch issue. Journal of Teacher Education for Sustainability, 18(1), 127-139.

Kaščák, O., \& Pupala, B. (2011). Neoliberálna pasca súšasnej vzdelávacej politiky a školskej praxe [The neoliberal trap of the current educational policy and school practice]. Manažment školy v praxi, 1, 14-18.

Kugelmass, J., \& Ainscow, M. (2004). Leadership for inclusion: A comparison of international practices. Journal of Research in Special Educational Needs, 4(3), 133-141.

Leo, E., \& Barton, L. (2006). Inclusion, diversity and leadership: Perspectives, possibilities and contradictions. Educational Management Administration \& Leadership, 34(2), 167-180.

McMaster, C. (2015). Inclusion in New Zealand: The potential and possibilities of sustainable inclusive change through utilising a framework for whole school development. New Zealand Journal of Educational Studies, 50(2), 239-253.

Nelson, T., Cassell, J. A., \& Arnold, H. B. (2013). A multicultural interdisciplinary inquiry into human-environmental relationships and sustainability education. Multicultural Education, 21(1), 2-6.

Rajovic, V., \& Jovanovic, O. (2013). The barriers to inclusive education: Mapping 10 years of Serbian teachers' attitudes toward inclusive education. Journal of Special Education and Rehabilitation, 14(3), 78-97.

Riehl, C. J. (2000). The principal's role in creating inclusive schools for diverse students: A review of normative, empirical, and critical literature on the practice of educational administration. Review of Educational Research, 70(1), 55-81.

Ryan, J. (2006). Inclusive leadership. San Francisco: Jossey-Bass.

Schensul, J. J. (2012). Methodology, methods, and tools in qualitative research. In S. D. Lapan, M. T. Quartaroli \& F. J. Riemer (Eds.), Qualitative research: An introduction to methods and designs (pp. 69-106). San Francisco, CA: Jossey-Bass.

Sindelar, P. T., Shearer, D. K., Yendol-Hoppey, D., \& Liebert, T. W. (2006). The sustainability of inclusive school reform. Exceptional Children, 72(3), 317-331.

Slee, R. (2011). The irregular school: Exclusion, schooling and inclusive education. Oxon: Routledge. 
Slee, R. (2013). How do we make inclusive education happen when exclusion is a political predisposition? International Journal of Inclusive Education, 17(8), 895-907.

Starks, C. (2013). Connecting multiculturalism, sustainability, and teacher education: A case of linking Martin Luther King Streets and the power of place. Multicultural Education, 21(1), 33-37.

Ward, S. C., Bagley, C., Lumby, J., Woods, P., Hamilton, T., \& Roberts, A. (2015). School leadership for equity: Lessons from the literature. International Journal of Inclusive Education, 19(4), 333-346.

Welch, A. R. (2010). Australian education in an era of markets, and managerialism - A critical perspective. In V. Masemann \& S. Majhanovich (Eds.), The state of comparative education. Rotterdam: Sense.

Wood, P. B., Spandagou, I., \& Evans, D. (2012). Principals' confidence in managing disruptive student behaviour: Exploring geographical context in NSW primary schools. School Leadership \& Management, 32(4), 375-395.

Žovinec, E., \& Seidler, P. (2010). Identifikácia a analýza problémových oblastí školskej inklúzie [Identification and analysis of problematic areas of school inclusion]. In V. Lechta (Ed.), Transdisciplinárne aspekty inkluzíunej pedagogiky [Transdisciplinary aspects of inclusive pedagogy]. Bratislava: EMITplus.

Correspondence concerning this paper should be addressed to Jozef Miškolci, PhD, Comenius University in Bratislava, Faculty of Education, M-213, Račianska 59, 813 34, Bratislava, Slovakia. Email: jozef.miskolci@uniba.sk 